\title{
PENGAWASAN KREDIT PADA BANK NAGARI CABANG SITEBA
}

\author{
Susi Ana Saputri, Jhon Fernos \\ Akademi Keuangan Perbankan "Pembangunan" Padang \\ Jhonfernos@akbpstie.ac.id
}

\begin{abstract}
Bank Nagari Branch Siteba was established with the Deed of establishment number based on Notarial Deed of Hasan Qalbi, SH. In Padang, on March 12, 1962 as the legal basis for the establishment of the Nagari Branch Bank of Nagari with an initial capital of Rp.50 billion and paid up capital of Rp. 150 billion. The main activities of Bank Nagari in Siteba Branch are lending, types of loans channeled are investment loans, working capital loans, productive loans, consumer loans, trade loans, short-term loans, mediumterm loans, long-term loans, collateral loans, loans without collateral, agricultural credit, livestock credit, industrial credit, mining credit, education credit, professional credit and housing loans. Credit supervision carried out by Nagari Branch Bank Siteba starts from the application stage by checking the completeness of the credit file and conducting a system of direct supervision of the customer's business. For debtors who do not pay installments or arrears have occurred, they will be given a warning letter. Based on the data obtained by Collectable and MPL credits conducted by NagariCabangSitebabaik Bank.
\end{abstract}

Keywords: Bank, Credit Supervision

\section{PENDAHULUAN}

Secara umum lembaga keuangan dapat dikelompokkan dalam dua bentuk yaitu Bank dan Bukan Bank. Undang-undang RI NO.10 Tahun 1998 Tentang Perbankan mengemukakan bahwa bank adalah badan usaha yang menghimpun dana dari masyarakat dalam bentuk simpanan dan menyalurkan kepada masyarakat dalam bentuk kredit atau bentuk-bentuk lainnya dalam rangka meningkatkan taraf hidup rakyat.

Dalam persaingan dunia bisnis terutama dalam lembaga keuangan perlu adanya pengawasan guna mempermudah terjadinya transaksi dalam pemberian kredit yang akan berimplikasi terhadap berbagai aspek, seperti: terhadap lembaga keuangan yang terlibat, aspek hukum pihak-pihak yang terkait, mekanisme penyelesaian risiko, yang kesemuanya itu dapat memberikan dampak kepada sistem lembaga keuangan dan perekonomian.

Pada dasarnya pengembangan perekonomian masyarakat, ditunjukan pada dua pokok yaitu meningkatkan kemampuan produksi, serta terciptanya lapangan kerja baru bagi angkatan kerja yang setiap tahunnya meningkat, namun dikarenakan adanya keterbatasan modal produksi dalam usaha meningkatkan perekonomian tersebut, bantuan dari bank dalam bentuk tambahan modal atau yang disebut dengan kredit yang sangat dibutuhkan. Hal ini disebabkan karena kebutuhan masyarakat beraneka 
ragam selalu meningkat, sementara kemampuan untuk mencapai sesuatu yang diinginkan terbatas sehingga terjadilah kesenjangan antara kemampuan dan cita-cita.

Bank merupakan salah satu lembaga keuangan yang mempunyai peranan yang sangat penting bagi aktivitas perekonomian. Dalam upaya

mencapai tujuan pembangunan yang dilakukan, baik kebijakan fiskal maupun kebijakan moneter yang dilakukan oleh pemerintah yaitu di bidang perbankan. Bank sebagai badan usaha yang berorientasi pada pencapaian keuntugan (profit orientied). Dalam hal ini fungsi utama bank adalah sebagai perantara antara masyarakat kelebihan dana dengan masyarakat kekurangan dana, maka usaha pokok yang dilaksanakan bank adalah kegiatan-kegiatan pada sektor perkreditan, atau penyaluran dana. Sehingga secara otomatis pendapatan bank yang terbesar diperoleh dari sektor perkreditannya.Semakin tinggi volume perkreditannya maka semakin besar pula kemungkinan suatu bank untuk pencapaian profitabilitas.Dengan demikian perlu dilakukan pengelolaan perbankan secara profesional terutama dalam sektor perkreditannya.Dengan dilakukannya pengelolaan kredit secara profesional diharapkan dapat meningkatkan likuiditas dan profitabilitas bank.

Manajemen kredit sangat penting dilakukan dalam penyaluran dana agar bank tidak mengalami kredit bermasalah karena pada kenyataannya kredit yang diberikan kepada nasabah banyak mengalami kendala, salah satu alat yang tepat dan efektif dalam menangani rmasalah kredit, yaitu melaksanakan fungsi pengawasan dengan baik.

Pengawasan kredit menurut hasibuan (2001:105) adalah usaha-usaha untuk menjaga kredit yang diberikan tetap lancar, produktif dan tidak macet.Lancar dan produktif artinya kredit itu dapat ditarik kembali bersama bunganya sesuai dengan perjanjian yang telah disetujui kedua belah pihak. Hal ini penting karena jika terjadi kredit macet, maka bank yang bersangkutanlah yang akan menanggung kerugiannya.

Untuk kelangsungan usaha bank sangat ditentukan oleh kesiapan bank untuk menghadapi risiko kerugian dari kredit yang disalurkan. Oleh karena itu bank perlu melakukan pengawasan lebih awal terhadap nasabah yang akan mendapatkan fasilitas kredit.

Bank Nagari Cabang Siteba merupakan salah satu lembaga keuangan yang ikut berpartisipasi dalam mewujudkan pemerataan kesejahteraan masyarakat melalui pemberian fasilitas kredit pada masyarakat umum dan pengusaha pada khususnya.Pelaksanaan pengawasan yang dilakukan oleh Bank Nagari Cabang Siteba didasarkan pada penilaian atas laporan-laporan dan kelengkapan file-file serta pemeriksaan langsungketempat usaha nasabah. Dengan dilakukan pengawasan ini, maka Bank Nagari Cabang Siteba akan dapat menilai apakah kredit yang diberikan oleh bank pada nasabah benar-benar digunakan sesuai dengan proposal yang diajukan oleh nasabah.

Untuk mengantisipasi terjadinya kredit bermasalah maka pengawasan kredit mutlak dilakukan pihak bank karena berdampak pada tingkat kesehatan bank dan kelangsungan bank itu sendiri. 
Tabel 1

Data Posisi Kualitas Kredit Kolektibility

Bank Nagari Cabang Siteba

Tahun $2012-2015$

(dalam ribuan rupiah)

\begin{tabular}{|l|c|c|c|c|c|}
\hline Tahun & $\begin{array}{c}\text { L } \\
(1)\end{array}$ & $\begin{array}{c}\text { DPK } \\
(2)\end{array}$ & $\begin{array}{c}\text { KL } \\
(3)\end{array}$ & $\begin{array}{c}\text { D } \\
(4)\end{array}$ & $\begin{array}{c}\text { M } \\
(5)\end{array}$ \\
\hline 2012 & 207.612 .846 & 5.250 .755 & 238.535 & 613.300 & 5.250 .708 \\
\hline 2013 & 257.171 .526 & 5.675 .056 & 575.000 & 335.000 & 5.823 .493 \\
\hline 2014 & 285.849 .634 & 9.035 .436 & 165.000 & 727.000 & 5.934 .300 \\
\hline 2015 & 327.223 .322 & 8.454 .500 & 720.000 & 1.235 & 7.956 .936 \\
\hline
\end{tabular}

Sumber : Bank Nagari Cabang Siteba

Keterangan :

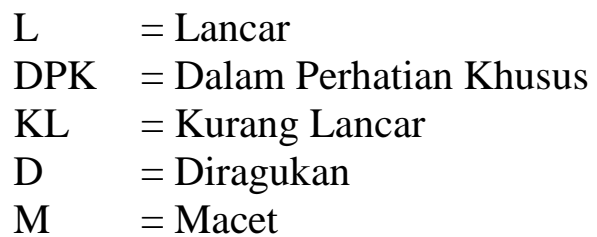

Berdasarkan uraian diatas dapat kita lihat perkembangan jumlah kredit yang disalurkan oleh bank nagari cabang siteba dari tahun 2012 - 2015. Dari tahun 2012 ketahun 2015 perkembangan jumlah kredit pada bank nagari cabang siteba terus meningkat dari tahun ketahun.Pada kolom 4 dan 5 kredit yang dilakukan Bank Nagari Cabang Siteba kurang baik, sehingga terjadi kredit bermasalah. Maka dari itu penulis tertarik untuk mengetahui lebih dalam sejauh mana peranan pengawasan kredit yang dilakukan Bank Nagari Cabang Siteba.

Melihat pentingnya pengawasan kredit dan supaya nasabah konsisten terhadap perjanjian yang telah disepakati sebelumnya, maka penulis tertarik untuk melakukan penelitian dengan judul ' Pengawasan Kredit Pada Bank Nagari Cabang Siteba'.

Berdasarkan latar belakang yang telah diuraikan diatas, maka yang dibahas dalam tugas akhir ini yaitu tentang Bagaimana pengawasan kredit pada Bank Nagari Cabang Siteba.

\section{LANDASAN TEORI}

Pengertian Bank

Bank merupakan salah satu bentuk lembaga keuangan yang berperan sebagai lembaga keuangan (financial intermediary) antara pihak-pihak yang memiliki kelebihan dana (surplus unit) dengan pihak-pihak yang memerlukan dana, serta sebagai lembaga yang berfungsi memperlancar lalu lintas pembayaran. Menurut UU Nomor 10 tahun 1998 tenteng perbankan, bahwa bank adalah badan usaha yang menghimpun dana dari masyarakat dala bentuk kredit atau bentuk lainnya dalam meningkatkan taraf hidup rakyat banyak.

\section{Pengertian Kredit}

Dalam bahasa sehari-hari kredit sering diartikan memperoleh barang dengan cicilan atau dengan angsuran dikemudian hari atau memperoleh pinjaman uang yang 
pembayarannya dilakukan dikemudian hari dengan cicilan atau angsuran sesuai dengan perjanjian.Baik kredit berbentuk barang atau berbentuk uang.Baik kredit berbentuk barang maupun kredit berbentuk uang dalam hal pembayaran adalah dengan menggunakan metode angsuran atau cicilan tertentu.Kredit dalam bentuk uang lebih dikenal dengan istilah pinjaman.Dengan ini pengertian pemberian kredit disamping dengan istilah pinjaman oleh bank yang berdasarkan prinsip konvensional adalah istilah pembiayaan yang digunakan oleh bank berdasarkan prinsip syariah.

Menurut UU perbankan No. 10 tahun 1998 yang dimaksud dengan kredit adalah penyediaan uang atau tagihan yang dapat dipersamakan dengan itu berdasarkan persetujuan atau kesepakatan pinjam meminjam antara bank dengan pihak lain yang mewajibkan pihak peminjam untuk melunasi hutangnya setelah jangka waktu tertentu dengan pemberian bunga.

\section{Fungsi dan Tujuan Kredit}

Rivai dan Veithzal (2006:6) mengatakan bahwa "pada dasarnya terdapat dua fungsi yang saling berkaitan dari kredit, yaitu profitability dan safety".Profitability yaitu, tujuan untuk memperoleh hasil dari kredit berupa keuntungan dari bunga yang harus dibayar nasabah, sedangkan safety merupakan keamanan dari prestasi atau fasilitas yang diberikan harus benar-banar terjamin sehingga tujuan profitability dapat tercapai tanpa hambatan yang berarti.

\section{Pengertian Pengawasan Kredit}

Pengawasan merupakan fungsi pokok dari manajemen. Pengawasan kredit itu merupakan suatu proses internal control mulai saat permohonan sampai dengan kredit dilunasi. Pengawasa kredit diartikan salah satu fungsi manajemen berupaya untuk menjaga dan mengamankan kredit itu sebagai kekayaan bank dan dapat mengetahui asumsi-asumsi dasar persetujuan, kredit itu akan tercapai atau malah terjadinya penyimpangan.

\section{Fungsi dan Tujuan Pengawasan Kredit}

Pengawasan kredit mempunyai fungsi untuk mengetahui secara dini penyimpangan yang terjadi atas penyaluran kredit kepada debitur.Pengawasan kredit dapat membantu bank untuk dapat segera mengambil langkah-langkah yang tepat dan cepat serta dapat mendeteksi penyimpangan sedini mungkin untuk mengantisipasi kemungkinan timbulnya masalah kredit. (Arthesa, 2006:180)

\section{Teknik Pengawasan Kredit}

Didalam pengawasan kredit yang dilakukan oleh Bank Nagari Cabang Siteba dapat bersifat aktif dan pasif yaitu :

1. Pengawasan aktif

Pengawasan aktif adalah pengawasan secara langsung dari pegawai baik pengurus kredit maupun pejabat yang terjun langsung kepada nasabah untuk melihat perkembangan usaha nasabah memberikan bantuan manajemen, memberikan dorongan serta memantau alur yang diberikan.Teknik pelaksanaan pengawasan aktif dilakukan dengan membuat strategi yang tepat untuk mengunjungi nasabah atau debitur lainnya, karena pengawasan yang dilakukan secara langsung sehingga pegawai perlu terjun langsung kelapangan.

2. Pengawasan pasif

Pengawasan pasif adalah pengawasan yang dilakukan melalui laporan-laporan tertulis yang dilakukan seperti laporan keadaan keuangan ( dari neraca dan laporan laba rugi ), laporan penyaluran keuangan ( dari mutasi pinjaman ). Pengawasan ini 
merupakan pengawasan yang dilakukan secara tidak langsung sehingga pegawai tidak perlu terjun langsung kelapangan.

\section{Proses dan Jenis Pengawasan Kredit}

Pengawasan merupakan fungsi manajemen yang menepati urutan paling akhir dalam fungsi manajemen.Pengawasan membantu penilaian apakah perencanaan, pengorganisasian, dan pelaksanaan suatu program telah dilaksanakan dengan efektif atau tidak. Kegiatan pengawasan kredit mencakup unsur-unsur yang berupa langkah sebagai berikut :

1. Menetapkan Kriteria Pengawasan

Sebelum melakukan suatu pengawasan terhadap kredit suatu bank harus terlebih dahulu menetapkan kriteria pengawasan.

2. Melakukan Proses Penilaian

Setelah perusahaan mengetahui atau menetapkan proses pengawasan bank juga melakukan proses penilaian. Tindakan ini dilakukan secara umum dan khusus dengan memperbandingkan kinerja, norma dan tujuan pemberian kredit.

\section{Aspek-Aspek Pengawasan Kredit}

Disamping penilaian dengan $5 \mathrm{C}$ dan $7 \mathrm{P}$ prinsip penilaian kredit dapat pula dilakukan dengan studi kelayakan, terutama untuk kredit dalam jumlah yang bersifat relative besar. Adapun penilaian kredit dengan studi kelayakan meliputi :

1. Aspek hukum

2. Aspek pasar dan pemasaran

3. Aspek keuangan

4. Aspek operasi teknis

5. Aspek manajemen

6. Aspek ekonomis social

7. Aspek AMDAL

Aspek yang meliputi pengawasan kredit :

1. Adanya administrasi kredit yang memadai dan mengadakan cara-cara mutakhir, seperti penggunaan computer on line system.

2. Keharusan bagi nasabah kredit untuk menyampaikan laporan secara berkala atas jenis-jenis laporan yang telah disepakati dan dituangkan dalam perjanjian kredit .

3. Kaharusan yang wira kredit ( account officer ) melakukan kunjungan ( visit ) perusahaan atau proyek yang dibiayai bank, baik selama berlangsungnya pembangunan proyek maupun setelah proyek tersebut berjalan sebagai suatu usaha bisnis.

4. Adanya konsultasi yang terstruktur antara pihak bank dengan debitur, terutama jika debitur memulai mengalami kesulitan dalam bisnisnya atau telah menunjukan tanda-tanda terjadinya kemacetan.

5. Adanya suatu " system peringatan " ( warning system ) pada administrasi bank atau pada umumnya dikelola oleh wira kredit mengenai nasabah yang bersangkutan peringatan dini tersebut dapat memperlihatkan kepada kepada wira kredit berbagai informasi tentang nasabah kredit yang berkaitan dengan kepatuhan kepada ketentuan yang telah dibuat dalam perjanjian kredit

Pengawasan kredit mengandung aspek-aspek pokok, yaitu sebagai berikut :

1. Aspek Adminitratif yaitu meliputi penguasaan dan penata usahaan proses kegiatan kredit sejak awal sampai pelunasan. 
2. Aspek Supervise yaitu secara terus-menerus mengikuti perkembangan kredit dan usaha nasabah, agar bank mampu mengetahui actual performance kredit yang tercermin pada kolektibilitasnya.

3. Aspek Penagihan yaitu penarikan kembali kredit sesuai jadwal dengan tidak mengganggu berjalannya kegiatan usaha nasabah, kecuali ada sinyal bahwa ada penurunan mutu kredit yang terus menerus agar bank terhindar dari kerugian.

\section{METODE PENELITIAN}

Dalam pengumpulan data dan bahan untuk penelitian ini digunakan metode penelitian sebagai berikut :

1. Metode Pengumpulan Data

a. Field research ( Studi Lapangan)

Pada studi lapangan, dilakukan studi langsung ke Bank Nagari Cabang Siteba agar didapatkan data-data serta keterangan-keterangan yang diperlukan dalam penelitian.

b. Library research ( Studi Kepustakaan)

Mengumpulkan data-data dan teori-teori yang berkaitan dengan masalah yang dibahas melalui literatur-literatur yang ada baik berupa buku-buku maupun majalah-majalah ilmiah yang berkaitan dengan penelitian

2. Metode Analisa Data

Dalam menganalisa data,menggunakan analisa data kualitatif dan kuantitatif. Dimana metode kualitatif menggambarkan, memahami dan menjelaskan data yang diteliti selama penelitian berlangsung, sedangkan metode kuantitatif menganalisa mengenai pengawasan kredit, melalui kualitas kredit kolektibility,tingkat NPL dan perkembangan jumlah kredit pada Bank Nagari Cabang Siteba.

\section{HASIL DAN PEMBAHASAN \\ Analisa Pengawasan Kredit}

Kegiatan utama Bank Nagari Cabang Siteba adalah menyalurkan dana dalam bentuk kredit kepada masyarakat terutama untuk pengusaha atau pedagang yang membutuhkan modal untuk pengembangan usahanya. Adapun jenis-jenis kredit yang disalurkan oleh Bank Nagari Cabang Siteba adalah sebagai berikut :

1. Dilihat dari segi kegunaan

a. Kredit investasi

Biasanya digunakan untuk keperluan perluasan usaha atau membangun proyek/pabrik baru atau untuk keperluan rehabilitas.

b. Kredit modal kerja

Digunakan untuk keperluan meningkatkan produksi dalam operasiaonalnya. Dilihat dari segi tujuan kredit

a. Kredit produktif

Kredit yang digunakan untuk peningkatan usaha atau produksi atau investasi.Kredit ini digunakan untuk menghasilkan barang atau jasa.

b. Kredit konsumtif

Kredit yang digunakan untuk dikonsumsi secara pribadi.Dalam kredit ini tidak ada pertambahan barang dan jasa yang dihasilkan, karena memang untuk digunakan atau dipakai oleh seseorang atau badan usaha.

2. Dilihat dari segi jangka waktu 
a. Kredit jangka pendek

Merupakan kredit yang memiliki jangka waktu kurang dari 1 tahun atau paling lama 1 tahun dan biasanya digunakan untuk keperluan modal kerja.

b. Kredit jangka menengah

Jangka waktu kreditnya berkisar antara 1 tahun sampai dengan 3 tahun, biasanya untu investasi.

c. Kredit jangka panjang

Merupakan kredit yang masa pengembaliannya paling panjang.Kredit jangka panjang pengembaliannya diatas 3 tahun atau 5 tahun.Biasanya kredit ini untuk investasi jangka panjang.

3. Dilihat dari segi jaminan

a. Kredit dengan jaminan

Kredit yang diberikan dengan suatu jaminan, jaminan tersebut dapat berbentuk barang berwujud atau tidak berwujud atau jaminan orang. Artinya setiap kredit yang dikeluarkan akan dilindungi senilai jaminan yang diberikan sicalon debitur.

b. Kredit tanpa jaminan

Merupakan kredit yang diberikan tanpa jaminan barang atau orang tertentu. Kredit jenis ini diberikan dengan melihat prospek usaha dan karakter serta loyalitas atau nama baik si calon debitur selama ini.

4. Dilihat dari segi sektor usaha

a. Kredit pertanian, merupakan kredit yang dibiayai untuk sektor perkebunan atau pertanian rakyat.

Sektor usaha pertanian dapat berupa jangka pendek atau jangka panjang.

b. Kredit perternakan, dalam hal ini untuk jangka pendek misalnya peternakan ayam dan jangka panjang kambing atau sapi.

c. Kredit industri, yaitu kredit untuk membiayai industri kecil, menengah atau besar.

d. Kredit pertambangan, jenis usaha tambang yang dibiayainya biasanya dalam jangka panjang, seperti tambang emas, minyak atau timah.

e. Kredit pendidikan, merupakan kredit yang diberikan untuk membangun sarana dan prasarana pendidikan atau dapat pula berupa kredit untuk para mahasiswa.

f. Kredit profesi, diberikan kepada profesional seperti dosen, dokter atau pengacara.

g. Kredit perumahan, yaitu kredit untuk membiayai pembangunan atau pembelian perumahan.

h. Dan sektor-sektor lainnya.

Adapun proses pengawasan kredit yang dilakukan oleh Bank Nagari Cabang Siteba adalah sebagai berikut :

1. Sebelum realisasi pencairan kredit :

a. Melihat kebenaran data-data kelengkapan berkas kredit.

b. Pemantauan usaha nasabah dan melihat laporan keuangannya.

c. Penilaian terhadap prinsip-prinsip pemberian kredit, yaitu ada 2 prinsip yang pertama prinsip $5 \mathrm{C}$ adapun penjelasan untuk prinsip $5 \mathrm{C}$ adalah sebagai berikut :

1) Character yaitu suatu keyakinan bahwa, sifat atau watak dari orang-orang yang akan diberikan kredit benar-benar dapat dipercaya, hal ini tercermin 
dari latar belakang si nasabah baik yang bersifat pribadai seperti : cara hidup atau gaya hidup yang dianutnya, keadaan keluarga, hoby dan sosial standingnya. Ini semua merupakan ukuran "kemauan" membayar.

2) Capacity yaitu $u$ ntuk melihat nasabah dalam kemampuannya dalam bidang bisnis yang dihubungkan dengan pendidikannya, kemampuan bisnis juga diukur dengan kemampuannya dalam memahami tentang ketentuanketentuan pemerintah.Begitu pula dengan kemampuannya dalam menjalankan usahanya selama ini. Pada akhirnya akan terlihat "kemampuannya" dalam mengembalikan kredit yang disalurkan.

3) Capital yaitu $u$ ntuk melihat kegunaan modal apakah efektif, dilihat laporan keuangan (neraca dan laporan laba rugi) dengan melakukan pengukuran seperti dari segi likuiditas, solvabilitas, rentabilitas, dan ukuran lainnya. Capital juga harus dilihat dari sumber mana saja modal yang ada sekarang ini.

4) Colleteral yaitu merupakan jaminan yang diberikan calon nasabah baik yang bersifat fisik maupun non fisik.Jaminan hendaknya melebihi jumlah kredit yang diberikan. Jaminan juga harus diteliti keabsahannya sehingga jika terjadi suatu masalah, maka jaminan yang dititipkan akan dapat dipergunakan secepat mungkin.

5) Condition yaitu dalam menilai kredit hendaknya juga dinilai kondisi ekonomi dan politik sekarang dan dimasa yang akan datang sesuai sektor masing-masing, serta prospek usaha dari sektor yang ia jalankan. Penilaian prospek bidang usaha yang dibiayai hendaknya benar-benar memiliki prospek yang baik sehingga kemungkinan kredit tersebut bermasalah relatif kecil.

Kemudian adapun penjelasan untuk prinsip $7 \mathrm{P}$ adalah sebagai berikut :

1) Personality yaitu menilai nasabah dari segi kepribadiannya atau tingkah lakunya sehari-hari maupun masa lalunya.Personality juga mencakup sikap, emosi, tingkah laku, dan tindakan nasabah dalam menghadapi suatu masalah.

2) Party yaitu mengklasifikasikan nasabah kedalam klasifikasi tertentu atau golongan-golongan tertentu berdasarkan modal, loyalitas serta karakternya. Sehingga nasabah dapat dilongkan kegolongan tertentu dan akan mendapatkan fasilitas yang berbeda dari bank.

3) Perpose yaitu untuk mengetahui tujuan nasabah dalam mengambil kredit, termasuk jenis kredit yang diinginkan nasabah.Tujuan pengambilan kredit dapat bermacam-macam.Sebagai contoh apakah untuk modal kerja atau investasi, konsumtif atau produktif dan lain sebagainya.

4) Prospect yaitu untuk menilai usaha nasabah dimasa yang akan datang menguntungkan atau tidak, atau dengan kata lain mempunyai prospek atau sebaliknya. Hal ini penting mengingat jika suatu fasilitas kredit yang dibiayai tanpa mempunyai prospek, bukan hanya bank yang rugi, tetapi juga nasabah.

5) Payment yaitu merupakan ukuran bagaimana cara nasabah mengembalikan kredit yang telah diambil atau dari sumber mana saja dana untuk pengembalian kredit. 
Semakin banyak sumber penghasilan debitur, akan semakin baik. Dengan demikian, jika salah satu usahanya merugikan dapat ditutupi oleh sektor lainnya.

6) Profitability yaitu untuk menganalisis bagaimana kemampuan nasabah dalam mencari laba.Profitability diukur dari periode ke periode apakah akan tetap sama atau akan semakin meningkat, apalagi dengan tambahan kredit yang akan diperolehnya.

7) Protection yaitu tujuannya adalah bagaimana menjaga agar usaha dan jaminan mendapatkan perlindungan.Perlindungan dapat berupa jaminan barang atau orang atau jaminan asuransi.

d. Penilaian terhadap jaminan atau agunan kredit yang mencakup hal-hal sebagai berikut :

1. Bukti kepemilikan jaminan atau agunan kredit

2. Kondisi agunan (sehat atau tidak sehat) serta melakukan cek fisik terhadap agunan yang diberikan dengan tujuan mengantisipasi hal-hal yang akan merugikan bank.

3. Perkiraan nilai jual kembali, dengan tujuan untuk mengawasi apabila nantinya terjadi kredit macet maka terhadap agunan dapat menutupi hutang nasabah.

4. Pengikatan agunan atau jaminan dengan surat kuasa jual dan pengikatan lainnya dengan tujuan untuk mengatasi apabila nantinya debitur tidak membayar hutangnya maka ditempuh dengan jalur pengadilan.

2. Tahap keputusan kredit

Setelah melakukan tahapan-tahapan sebelum keputusan kredit, maka akan dibuat keputusan apakah kredit tersebut akan ditolak atau diterima. Jika permohonan kredit diterima, maka akan disiapkan administrasinya dan jika ditolak akan dibatalkan kepada debitur secara tertulis. Keputusan kredit ini mencakup jumlah uang yang akan diterima, jangka waktu kredit, biaya-biaya yang harus dibayar, waktu pencairan kredit.

Sebelum kredit dapat dicairkan maka calon debitur menandatangani akad kredit yang formulirnya telah disediakan oleh bank, yang isi dan bentuknya telah dipersiapkan dan dicetak terlebih dahulu. Selain formulir perjanjian kredit, juga telah disiapkan perjanjian ikatan, yang merupakan perjanjian ikatan barang jaminan dan surat kuasa pengalihannya. Akad kredit dilakukan didepan notaris setelah penandatanganan syarat-syarat yang diperlukan.Maka debitur dapat merealisasikan kredit dengan membuka rekening giro atau tabungan dibank ini. Pada saat debitur melakukan penarikan, maka bank akan melakukan pencatatan terhadap provisi kredit dan pencatatan kredit yang ditarik oleh debitur.

3. Sesudah realisasi atau pencairan kredit.

Pengawasan kredit yang dilakukan Bank Nagari Cabang Siteba adalah pengawasan langsung yaitu sebagai berikut :

a. Pemantuan terhadap ketepatan nasabah dalam membayar angsuran kredit.

b. Pemantauan terhadap ketepatan penggunaan kredit.

c. Pemantauan terhadap usaha nasabah yang telah mendapatkan fasilitas kredit, dan yang dinilai adalah apakah sudah ada peningkatan jumlah penjualan serta penambahan barang modal.

d. Memberikan SP 1 (surat peringatan) kepada nasabah yang terlambat membayar angsuran atau menunggak 1 bulan. 
e. Memberikan SP 2 (surat peringatan) kepada nasabah yang terlambat membayar angsuran atau menunggak 2 bulan.

f. Memberikan SP 3 (surat peringatan) kepada nasabah yang terlambat membayar angsuran atau menunggak 3 bulan.

g. Apabila pembinaan terhadap kredit bermasalah sudah tidak dapat dilakukan lagi, dan sudah terjadi kredit macet maka akan dilakukan penyitaan terhadap agunan dan jaminan yang diberikan nasabah.

h. Barang agunan yang sudah disita akan dibuat dalam berita acara dan kepada nasabah akan diberikan tenggang waktu untuk membayar kewajibannya, apabila dalam waktu yang ditentukan nasabah belum juga membayar kewajibannya maka akan dilakukan pelelangan agunan atau melalui urusan pengadilan.

\section{Perkembangan Jumlah Kredit Bank Nagari Cabang Siteba}

Dana yang dihimpun oleh bank tersebut harus disalurkan ke masyarakat dalam bentuk kredit. Hal ini dilakukan karena fungsi bank adalah sebagai lembaga perantara (intermediary) antara pihak-pihak yang kelebihan dana dengan pihak yang kekurangan dana, dan keuntungan bank diperoleh dari selisih anatara harga beli dana tersebut setelah dikurangi dengan biaya operasional. Dengan demekian bank harus mampu menempatkan dana tersebut pada tempat yang paling menguntungkan serta bank juga harus malakukan fungsi pengawasan dengan baik.

Adapun perkembangan jumlah kredit yang disalurkan oleh Bank Nagari Cabang Siteba setiap tahunnya, baik itu kredit kredit investasi, kredit modal kerja, kredit produktif, kredit konsumtif, kredit perdagangan, kredit jangka pendek, kredit jangka menengah, kredit jangka panjang, kredit dengan jaminan, kredit tanpa jaminan, kredit pertanian, kredit peternakan, kredit industri, kredit pertambangan, kredit pendidikan, kredit profesi dan kredit perumahan dapat dilihat pada tabel 1.2 dibawah ini :

\section{Tabel 2}

\section{Data Posisi Kualitas Kredit Kolektibility}

Bank Nagari Cabang Siteba

Tahun $2012-2015$

(dalam ribuan rupiah)

\begin{tabular}{cccccc}
\hline Tahun & L & DPK & KL & D & M \\
& $(1)$ & $(2)$ & $(3)$ & $(4)$ & $(5)$ \\
\hline 2012 & 207.612 .846 & 5.250 .755 & 238.535 & 613.300 & 5.250 .708 \\
2013 & 257.171 .526 & 5.675 .056 & 575.000 & 335.000 & 5.823 .493 \\
2014 & 285.849 .634 & 9.035 .436 & 165.000 & 727.000 & 5.934 .300 \\
2015 & 327.223 .322 & 8.454 .500 & 720.000 & 1.235 & 7.956 .936 \\
\hline
\end{tabular}

Sumber : Bank Nagari Cabang Siteba, Data diolah

Keterangan :
a. L = Lancar
b. DPK = Dalam Perhatian Khusus
c. $\mathrm{KL}=$ Kurang Lancar
d. $\mathrm{D}=$ Diragukan
e. $\mathrm{M}=$ Macet

Berdasarkan uraian diatas dapat kita lihat perkembangan jumlah kredit yang disalurkan oleh bank nagari cabang siteba dari tahun 2012 - 2015. Dari tahun 2012 ketahun 2015 perkembangan jumlah kredit pada Bank Nagari Cabang siteba terus meningkat dari tahun ketahun.Pada kolom 4 dan 5 kredit yang dilakukan Bank Nagari Cabang Siteba kurang baik, bisa dilihat pada kolom ke 4 yang diragukan 
tahun 2012 ke tahun 2013 adanya kredit yang diragukan menurun dari 613.300 turun menjadi 335.000, ditahun 2013 ketahun 2014 kredit yang diragukan naik kembali dari 335.000 menjadi 727.000, ditahun 2014 ketahun 2015 kredit yang diragukan turun kembali dari 727.000 menjadi 1.235.Berdasarkan kenaikan atau pun penurunan jumlah kredit yang diragukan pada Bank Nagari Cabang Siteba dapat kita simpulkan bahwa jumlah kredit yang diragukan tidak stabil karna masih adanya kenaikan dan penurunan dari tahun ke tahun, dan bisa dikatakan tidak baik.Pada kolom ke5 yaitu kolom jumlah kredit macet pada Bank Nagari Cabang Siteba dari tahun 2012 ke tahun 2015, pada tahun 2012 ke tahun 2013 jumlah kredit yang macet mengalami kenaikan yaitu dari 5.250.708 meningkat menjadi 5.823.493, pada tahun 2013 ketahun 2014 jumlah kredit yang macet mengalami kenaikan kembali dari 5.823.493 meningkat menjadi 5.934.300, pada tahun 2014 ketahun 2015 jumlah kredit yang macet mengalami kenaikan kembali dari5.934.300 menjadi 7.956.936. .Berdasarkan kenaikan atau pun penurunan jumlah kredit yang macet pada Bank Nagari Cabang Siteba dapat kita simpulkan bahwa jumlah kredit yang macet tidak stabil karna masih adanya kenaikan dan penurunan dari tahun ke tahun sehingga terjadi kredit bermasalah.

Adapun faktor terjadinya kredit yang diragukan dan kredit macet itu meningkat dan menurun adalah :

1. Perilaku rekening sering mengalami overdraft, terjadi penurunan saldo secara mencolok, pembayaran tersendat-sendat, sering mengajukan permintaan penundaan pembayaran, dan mengajukan perubahan jadwal pembayaran.

2. Perilaku laporan keuangan seperti likuiditas menurun, perputaran piutang menurun, persediaan meningkat, utang jangka panjang meningkat tajam, munculnya hutang dari kreditur lain dan laporan keuangan tidak audit.

3. Perilaku bisnis seperti hubungan dengan pengecer dan pelanggang menurun, harga jual terlampau rendah, ada informasi negatif dari pihak luar, perubahan mendadak dalam manajemen, dan mencari pinjaman baru.

4. Perilaku nasabah seperti kesehatan nasabah menurun, nasabah meninggal, membeli aktiva tetap yang konsumtif, dan nasabah mempunyai kegiatan tertentu.

5. Perilaku nasabah lainnya yang dapat dibaca sebagai situasi yang memberikan indikasi bahwa kredit yang diperoleh nasabah ada gejala bermasalah yaitu nasabah kalah judi, terjadi sengketa rumah tangga, nasabah kawin lagi, telepon dari bank sering tidak dijawab.

Untuk melihat berapa besar kredit yang berada dalam kondisi kurang lancar, diragukan, dan macet dibandingkan dengan total jumlah kredit yang diberikan. Sesuai dengan ketentuan dari Bank Indonesia dengan SE No. 6/23/DPNP tanggal 31 Mei 2004, dikatakan bahwa tingkat NPL yang dikatakan baik apabila kurang dari $5 \%(<5 \%)$.

Rumus untuk perhitungan NPL ini adalah :

$N P L=$ Kredit Kurang Lancar + Diragukan + Macet $\quad x 100 \%$

\section{Total Kredit}


Perhitungan tingkat NPL :

1) Tahun $2012=\frac{238.535+613.300+5.250 .708}{218.966 .144} \times 100 \%$ $=2,40 \%$

2) Tahun $2013=\frac{575.000+335.300+5.823 .493}{269.580 .075} \times 100 \%$

$$
=2,16 \%
$$

3) Tahun $2014=\frac{165.000+727.000+5.934 .300}{301.711 .370} \times 100 \%$

$$
=1,96 \%
$$

4) Tahun $2015=720.000+1.235+7.956 .936 \times 100 \%$

$$
=2,31 \%
$$

Tabel 3

Tabel Perhitungan NPL

Bank Nagari Cabang Siteba

Tahun $2012-2015$

(Dalam ribuan rupiah)

\begin{tabular}{ccccc}
\hline Tahun & KL & D & M & $\begin{array}{c}\text { NPL } \\
\text { (KL+D+Mx100) } \\
\text { TK }\end{array}$ \\
\hline 2012 & 238.535 & 613.300 & 5.250 .708 & $2,40 \%$ \\
2013 & 575.000 & 335.000 & 5.823 .493 & $2,16 \%$ \\
2014 & 165.000 & 727.000 & 5.934 .300 & $1,96 \%$ \\
2015 & 720.000 & 1.235 & 7.956 .936 & $2,31 \%$ \\
\hline
\end{tabular}

Sumber : Bank Nagari Cabang Siteba, Data diolah

Dari hasil perhitungan tabel 3 diatas, dapat kita lihat tingkat NPL dari Bank Nagari Cabang Siteba. Sesuai dengan surat edaran Bank Indonesia No.6/23/DPNP pada tanggal 31 Mei 2004 dikatakan bahwa suatu bank dikatakan baik jika tingkat NPL $<5 \%$.

Pada tahun 2012 NPL lebih tinggi dari tahun-tahun lainya, meningkatnya NPL ini jika dibiarkan secara terus menerus akan memberikan pengaruh negatif pada bank. Dampak negatif tersebut salah satunya adalah mengurangi jumlah modal yang dimiliki oleh bank. Suku bunga memang merupakan salah satu sumber income bank yang mana jika bank tidak lagi menerima angsuran sesuai dengan jangka waktu yang telah ditentukan, maka dikhawatirkan hal ini akan terus memperburuk kondisi bank. Malihat kasus seperti ini, maka pihak bank memamg dituntut untuk melakukan analisa kredit sehingga bisa melakukan seleksi klien mana yang pantas untuk menerima dana pinjaman dari bank.

Faktor-faktor pemicu NPL meningkat dan turun pada lembaga keuangan sering kali memicu munculnya masalah diantaranya adalah dampak krisis sulit dimensional yang hingga saat ini membuat banyak dari para debitur bank tidak mampu menyelesaikan masalah kredit mereka yang macet. Faktor lain yang juga seringkali memicu masalah ini adalah tidak adanya i'tikad baik dari para debitur unuk segera menyelesaikan masalah ini.akibatnya tidak jarang bank atau lembaga keuangan akan menerima dampaknya dari kondisi ini. Tingginya suku bunga memang sering kali 
menjadi beban berat bagi para debitur untuk menelesaikan kewajiban mereka pada bank, sehingga mereka tidak mampu menyelesaikan kredit sesuai dengan kesepakatan yang telah dibuat.

Mengetahui seluk beluk apa itu NPL hal itu tidak cukup dalam dunia perbankan. Untuk menjaga bank dalam kondisi yang aman, maka sistem manajemn yang baik memang sangat perlu untuk diterapkan secar maksimal, melalui manajemen yang baik dalam berbagai kegiatan operasional bank terutama untuk hal-hal yang terkait dengan kredit ini, akan membantu menjaga kestabilan kondisi dalam bank. Bagaimana tidak, sebagaimana yang telah kita singgung diatas bahwa NPL bisa memberi pengaruh besar pada bank.

NPL yang juga dikenal dengan kredit bermasalah ini memang bisa berdampak pada berkurangnya modal bank. Jika hal ini dbiarkan maka yag pasti aka berdampak pada penyaluran kredit pada periode berikutnya.

Faktor-faktor yang mempengaruhi atau bahkan naik turunnya NPL itu sendiri, diantaranya adalah kemauan dari para debitur, kondisi perekonomian indonesia, dan juga kebijakan dari pemerintah. Sebagaimana fungsi bank atau lembaga keuangan yang memang difungsikan untuk menghimpun dan menyalurkan dana dari dan untuk rakyat. Untuk memaksimalkan hal ini dn tetap tekoordinir dengan baik, maka pihak bank memang harus membuat sistem manajemen pada berbagai aspek dan pihak yang terlibat. Langkah ini merupakan upaya yang cukup bagus dalam melakukan manajemen seluruh kegiatan operasional bank, diantaranya adalah untuk mengurangi resiko gagal kredit atau kredit macet yang akhirnya bisa menyebabkan bank tidak sehat.

Tabel 4

Perkembangan jumlah kredit

Bank Nagari Cabang Siteba

Tahun $2012-2015$

( Dalam ribuan rupiah )

\begin{tabular}{ccc}
\hline Tahun & Total kredit & $\begin{array}{c}\text { Pertumbuhan } \\
(\%)\end{array}$ \\
\hline 2012 & $219.233 .000 .00,-$ & - \\
2013 & $267.579 .000 .00,-$ & 23,6 \\
2014 & $301.710 .000 .00 .-$ & 26,6 \\
2015 & $345.588 .000 .00,-$ & 30,5 \\
\hline
\end{tabular}

Sumber : Bank Nagari Cabang Siteba

Dari tabel 4 diatas dapat dilihat perkembangan jumlah kredit yang disalurkan oleh Bank Nagari Cabang Siteba setelah data diolah secara keseluruhan mengalami peningkatan yang cukup berarti, hal ini terlihat dari kenaikan jumlah kredit yang disalurkan meningkat pada tahun ketahun, pada tahun 2013 ketahun 2014 total jumlah kredit meningkat dari Rp. 267.579.000.00,- menjadi Rp. 301.710.000.00,-, dengan pertumbuhan sebesar 23,6\% ke 26,6\% dan pada tahun 2014 ketahun 2015 total jumlah kredit meningkat kembali dari Rp. 301.710.000.00,- menjadi Rp. 345.588.000.00,-, dengan pertumbuhan sebesar $26,6 \%$ ke $30,5 \%$. Berdasarkan data-data yang telah diolah maka Bank Nagari Cabang Siteba bisa dikatakan memiliki total kredit yang baik karna mengalami kenaikan dari tahun ketahun.

Faktor-faktor yang mempengaruhi atau bahkan naik turunnya total kredit itu sendiri, diantaranya adalah kemauan dari para debitur, kondisi perekonomian indonesia, dan juga kebijakan dari pemerintah. Sebagaimana fungsi bank atau lembaga keuangan yang memang difungsikan untuk menghimpun dan menyalurkan dana dari dan untuk 
rakyat. Untuk memaksimalkan hal ini dan tetap tekoordinir dengan baik, maka pihak bank memang harus membuat sistem manajemen pada berbagai aspek dan pihak yang terlibat. Langkah ini merupakan upaya yang cukup bagus dalam melakukan manajemen seluruh kegiatan operasional bank, diantaranya adalah untuk mengurangi resiko gagal kredit atau kredit macet yang akhirnya bisa menghasilkan tingkat atau total kredit yang terus meningkat dengan baik.

\section{SIMPULAN}

Berdasarkan atas pemahaman teori dan pembhahasan yang telah diuraikan pada bab-bab sebelumnya, dapat dikemukakan beberapa kesimpulan sebagai berikut :

1. Bank Nagari Cabang Siteba didirikan dengan Akta Nomor pendirian berdasarkan Akta Notaris Hasan Qalbi,SH. Di Padang, pada tanggal 12 Maret 1962 sebagai dasar hukum pendirian Bank Nagari Cabang Siteba dengan modal awal Rp.50 milyar dan modal disetor Rp. 150 milyar.

2. Aktivitas utama Bank Nagari Cabang Siteba adalah menyalurkan kredit, jenis-jenis kredit yang disalurkan adalah kredit investasi, kredit modal kerja, kredit produktif, kredit konsumtif, kredit perdagangan, kredit jangka pendek, lredit jangka menengah, kredit jangka panjang, kredit dengan jaminan, kredit tanpa jaminan, kredit pertanian, kredit peternakan, kredit industri, kredit pertambangan, kredit pendidikan, kredit profesi dan kredit perumahan.

3. Pengawasan kredit yang dilakukan oleh Bank Nagari Cabang Siteba dimulai dari tahap permohonan dengan memeriksa kelengkapan berkas kredit serta melakukan sistem pengawasan langsung terhadap usaha nasabah. Bagi debitur yang tidak membayar angsuran atau sudah terjadi penunggakan maka akan diberi surat peringatan.

4. Berdasarkan data yang diperoleh kredit Kolektibilitasdan MPL yang dilakukan Bank NagariCabangSitebabaik.

\section{DAFTAR PUSTAKA}

Abdullah, Faisal, 2005. Manajemen Perbankan, Cetakan Ketiga, UMM Press, Malang.

Amelia, L., \& Marlius, D. (2018). Pengendalian Kredit Dalam Upaya Menciptakan Bank Yang Sehat Pada PT. Bank Pembangunan Daerah Sumatera Barat Cabang Utama Padang. https://doi.org/10.31227/osf.io/kpc64

Alanshari, F., \& Marlius, D. (2018). Prosedur Pemberian Kredit KPR Pada PT. Bank Tabungan Negara (Persero) TBK Cabang Pembantu Bukittinggi. https://doi.org/10.31227/osf.io/rsfhc

Baiya, \& Fernos, J. (2019). Analisis Faktor-Faktor Penyebab Kredit Macet Pada Bank Nagari Cabang Siteba. https://doi.org/10.31227/osf.io/4xuks

Budisantoso,T dan Sigit. 2006. Bank dan Lembaga Keuangan Lainnya.Edisi 2. Jakarta: Salemba Empat. 
Darmawanto, \& Fernos, J. (2019). Prosedur Pemberian Kredit Pada Bank Nagari Cabang Sijunjung. https://doi.org/10.31227/osf.io/psqfy

Direktorat Penelitian dan Pengaturan Perbankan, Bank Indonesia, 2001. Pedoman Akuntansi Perbankan Indonesia (PAPI), Revisi 2001, Jakarta.

Firmansyah, A., \& Fernos, J. (2019). Analisis Kredit Bermasalah Dilihat Dari Standar Non Performing Loan (NPL) Pada PT. Bank Perkreditan Rakyat (BPR) Prima Mulia Anugrah Cabang Padang. https://doi.org/10.31227/osf.io/gcj94

Hasibuan,Melayu SP. 2005. Dasar-dasar Perbankan.Jakarta: PT. Bumi Aksara

Hasibuan, Melayu, 2001. Dasar-Dasar Perbankan, Edisi Pertama, PT. Bumi Aksara. Jakarta.

Kasmir. SE., M.M. 2002. Dasar-dasar Perbankan. Jakarta: Raja Grafindo Persada.

Kasmir. S.E., M.M. 2008. Bank dan Lembaga Keuangan Lainnya. Jakarta: PT. Raja Grafindo Persada.

Mcleod, Raymond Jr dan George Schell. 2004. Sistem Informasi Manajemen, Edisi Kedelapan, PT. Intermasa. Jakarta Pusat.

Pratama, D., \& Fernos, J. (2019). Prosedur Pelaksanaan Kredit Usaha Rakyat (KUR) Pada PT. Bank Nagari Cabang Padang. https://doi.org/10.31227/osf.io/ag68j

Rivai, Veithzal dan Adriana Permata Vethzal. 2006. Credit Management Handbook, Edisi Pertama. Jakarta.

Sastradipoetra, Komaruddin, 2004. Strategi Management Bisnis Perbankan : Konsep dan Implementasi Untuk Bersaing. Penerbit Kappa Sigma

Shanjaya, A. R., \& Marlius, D. (2017). Peranan Laporan Keuangan Dalam Kebijaksanaan Pemberian Kredit Kepada Calon Nasabah Pada PT. BPR Batang Kapas. https://doi.org/10.31227/osf.io/uxmg6

Thomas Suyatno. 1997. Dasar-dasar Perkreditan. PT. Gramedia Pustaka Umum. Jakarta.

Tjoekam, Moh 1999. Perkreditan Bisnis Inti Bank Komersil : Konsep, Teknik \& Kasus, PT Gramedia Pustaka Utama, Jakarta.

Undang-undang Republik Indonesia No. 10. 1998. Undang-undang Perbankan.Jakarta: Sinar Grafika Offset. 